\title{
Identification of SSR and RAPD markers linked to a resistance allele for angular leaf spot in the common bean (Phaseolus vulgaris) line ESAL 550
}

\author{
Gilvan Ferreira da Silva, João Bosco dos Santos and Magno Antonio Patto Ramalho \\ Universidade Federal de Lavras, Departamento de Biologia, Lavras, MG, Brazil.
}

\begin{abstract}
The objective of this study was to identify RAPD and SSR markers associated with a resistant allele for angular leaf spot (Phaeoisariopsis griseola) from the line 'ESAL 550', derived from the Andean 'Jalo EEP 558' cultivar, to assist selection of resistant genotypes. The resistant line 'ESAL 550' and the susceptible cultivar 'Carioca MG' were crossed to generate $F_{1}$ and $F_{2}$ populations. One hundred and twenty $F_{2: 3}$ families were evaluated. The DNA of the 12 most resistant families was bulked and the same was done with the DNA of the 10 most susceptible, generating two contrasting bulks. One RAPD and one SSR marker was found to be linked in coupling phase to the resistant allele. The SSR marker was amplified by the primer PV-atct $001_{282 \mathrm{C}}$, and its distance from the resistant allele was $7.6 \mathrm{cM}$. This is the most useful marker for indirect selection of resistant plants in segregating populations. The RAPD marker was amplified by the primer OPP07 ${ }_{857 \mathrm{C}}$ linked in coupling phase to the resistant allele, and distant $24.4 \mathrm{cM}$. Therefore, this RAPD marker is not so useful in assisting selection because it is too far from the resistant allele.
\end{abstract}

Key words: Phaseolus vulgaris, Phaeoisariopsis griseola, DNA markers, resistance, bulk segregant analysis.

Received: March 19, 2003; Accepted: June 26, 2003.

\section{Introduction}

The consumption of common bean in Brazil has decreased more than $22 \%$ in the past 25 years, mainly due to irregular supplies and higher prices (Teixeira and Thung, 1994; Santos and Braga, 1998). Increasing grain yield may reverse this trend. The bean crop faces several threats such as diseases, among which angular leaf spot, caused by the fungus Phaeisariopsis griseola, is one of the most important (Paula-Jr and Zambolim, 1998).

The most efficient method of disease control is the use of resistant cultivars (Satorato and Rava, 1994; Paula-Jr and Zambolim, 1998). Although some information on resistance sources and genetic control is already available, the procedures for artificial inoculation are not yet accurate resulting in low selection gain (Sartorato and Rava, 1994). An alternative is to select under natural incidence of the disease, which generally occurs only in the dry season, when the inoculum pressure is enough to assure efficient selection. The use of molecular markers for identifying vertical resistance alleles stands as an important contribution for bean breeding, mainly because they enable selection of genotypes with one or more resistance alleles at any time.

Large variability has been found in the population of the pathogen (Sartorato and Rava, 1994; Paula-Jr and

Send correspondence to João Bosco dos Santos. E-mail: jbsantos@ufla.br.
Zambolim, 1998; Nietsche et al., 2000; Sartorato, 2002). However, most cultivars currently used in Brazil, and consequently the disease-causing races, are of Mesoamerican origin. Thus, resistance alleles of Andean origin, such as the one from 'Jalo EEP 558', should contribute to improving resistant cultivars in a more efficient and durable way. Like 'Jalo EEP 558' cultivar, the 'ESAL 550' line, selected as a pure line from it, share the same resistant allele. The objective of this study was to identify RAPD and SSR markers linked to the resistant allele of the line 'ESAL 550' to help selection of plants resistant to angular leaf spot.

\section{Material and Methods}

'ESAL 550' and 'Carioca MG' were crossed and the $F_{1}$ and $F_{2}$ generations were obtained. The 'ESAL 550' is a pure line selected within the 'Jalo EEP 558' cultivar, and possesses large, yellow seeds (about 50 g per 100 seeds), resistance to angular leaf spot and is incompatible to most small seeded cultivars of Mesoamerican origin. The 'Carioca MG' possesses seeds similar to those of the 'Carioca' cultivar, slightly smaller and darker (about $20 \mathrm{~g}$ per 100 seeds); and is highly susceptible to angular leaf spot, but is compatible to cross with 'ESAL 550'. One hundred and twenty $\mathrm{F}_{2: 3}$ families were used, whose phenotypes were evaluated from February to May in a field experiment with three replications under conditions of natural disease incidence (Bruzi et al., 2002). 


\section{DNA extraction}

Total DNA was extracted from all the $\mathrm{F}_{2: 3}$ families using the usual CTAB procedure (Rogers and Bendich, 1988; Hagiwara et al. 2001). About $2 \mathrm{~g}$ of young leaves were taken from 12 plants of each family, being one young leaflet of about $1 \mathrm{~cm}^{2}$ from each plant. The DNA of the 12 most resistant and of the 10 most susceptible families were bulked to make up the two contrasting bulks, one resistant and the other susceptible (Michelmore et al., 1991; Mackay and Caligari, 2000).

\section{RAPD and SSR analysis}

Each RAPD reaction contained $30 \mathrm{ng}$ of DNA; $100 \mu \mathrm{M}$ of each dNTPs; $0.4 \mu \mathrm{M}$ primer; $0.6 \mathrm{U}$ Taq DNA polymerase; $2.5 \mathrm{mM} \mathrm{MgCl} ; 20 \mathrm{mM} \mathrm{KCl} ; 50 \mathrm{mM}$ Tris $\mathrm{pH}$ 8.3; $250 \mu \mathrm{g}$ bovine serum albumin $/ \mathrm{mL} ; 1.0 \%$ Ficoll 400; $1 \mathrm{mM}$ tartrazine and pure water up to final volume of $16 \mu \mathrm{L}$ (Hagiwara et al. 2001). One thousand and eighty 10-mer primers from Operon Technologies were tested. The amplification reaction was conducted in a Gradient 5331 Eppendorf Master Cycler thermocycler, programmed for 39 cycles. In the first two cycles, the denaturation was conducted at $94{ }^{\circ} \mathrm{C}$ for $2 \mathrm{~min}$, the annealing at $37^{\circ} \mathrm{C}$ for $15 \mathrm{~s}$, and the elongation at $72{ }^{\circ} \mathrm{C}$ for $60 \mathrm{~s}$, followed by an additional 37 cycles, which differed for denaturation by $15 \mathrm{~s}$. A final extension was done for $2 \mathrm{~min}$ at $72{ }^{\circ} \mathrm{C}$. The DNA fragments were analyzed in $1 \%$ agarose gel electrophoresis (75 V 4-5 h) and photographed under UV light.

Thirty-two pairs of SSR primers for Phaseolus vulgaris were also tested (Yu et al., 2000). The reaction was performed in the same thermocycler, but the reactions consisted of $30 \mathrm{ng}$ DNA; $200 \mu \mathrm{M}$ of each dNTPs; $0.6 \mathrm{U}$ Taq DNA polymerase; $0.2 \mu \mathrm{M}$ of each primer; $50 \mathrm{mM}$ Tris $\mathrm{pH}$ 8,$3 ; 2.0 \mathrm{mM} \mathrm{MgCl} 2 ; 20 \mathrm{mM} \mathrm{KCl} ; 250 \mu \mathrm{g} / \mathrm{mL}$ BSA; $1 \%$ Ficoll $400 ; 1 \mathrm{mM}$ tartrazine, and pure water to a final volume of $18.5 \mu \mathrm{L}$. The PCR reaction included an initial denaturation at $95^{\circ} \mathrm{C}$ for two min, followed by 9 cycles with denaturation at $94{ }^{\circ} \mathrm{C}$, annealing at $68^{\circ} \mathrm{C}$ and extension at $72^{\circ} \mathrm{C}$ for $20 \mathrm{~s}$ each, plus 25 cycles with the annealing temperature at $60{ }^{\circ} \mathrm{C}$, and a final extension step for $10 \mathrm{~min}$ at $72{ }^{\circ} \mathrm{C}$. The DNA fragments were resolved in $3 \%$ agarose gel eletrophoresis ( $80 \mathrm{~V}$ and $4-5 \mathrm{~h}$ ) for bulk analysis, and in $2.5 \%$ agarose gel for the $120 \mathrm{~F}_{2: 3}$ families with the primers that detected polymorphism in the bulks.

\section{Data analysis}

The $\mathrm{F}_{2: 3}$ family segregation based on disease reaction, RAPD and SSR markers were analyzed by the $\chi^{2}$ test. Recombination frequencies between the resistance gene and one marker or between two markers were estimated according to Allard (1956), using the maximum likelihood procedure and the GQMOL software (Cruz and Schuster 2001). The standard error, confidence interval and LOD score were also estimated for each recombination frequency. The recombination frequencies estimated were also transformed in map units (cM) according to Haldane's function (Schuster, 2002) in which $r$ stands for recombination frequency: $\mathrm{cM}=[-\ln (1-2 \mathrm{r})] / 2$.

\section{Results and Discussion}

The phenotypic analysis of the $120 \mathrm{~F}_{2: 3}$ families from the cross 'ESAL 550' $x$ 'Carioca MG' presented a segregation of 90 resistant and 30 susceptible families, therefore, exactly three resistant to one susceptible $\left(\chi^{2}=0, p=100 \%\right)$, indicating a monogenic inheritance, with resistance being due to the dominant allele.

Similar results have been observed from other Mesoamerican resistance sources, such as cultivars 'Cornell 49-242' and 'MAR-2' (Niestche et al., 2000; Ferreira et al., 2000), and the line 'BAT 332' (Caixeta, 2002). 'Jalo EEP 558' is one of the few Andean beans used in Brazil and it has shown almost complete resistance for more than 30 years. Therefore, its resistance should be more durable because most cultivars grown in Brazil are derived from a Mesoamerican origin and the predominant races of the pathogen are surely adapted to overcome the resistance alleles of that origin (Vanderplank, 1963). Similar monogenic resistance was also observed in the Andean cultivar AND 277 to the 63-23 race of $P$. griseola, and this resistant allele was also tagged with a RAPD marker (Carvalho et al., 1998).

\section{Identification of RAPD and SSR markers}

One RAPD and one SSR marker presented segregation in $\mathrm{F}_{2: 3}$ families that confirmed the dominant simple inheritance (Table 1). These results are important because they show that these DNA fragments are inheritable, confirming them as genetic markers.

Based on co-segregation analysis, the RAPD marker amplified by the primer OPP07 showed to be in coupling phase, and the DNA fragment has around $857 \mathrm{bp}$. The second marker identified was a DNA fragment of 282 bp (Figure 1) amplified by the following SSR pair of primers (PV-atct 001): 5'CAATTAAAACTCAACCAACCCAA ATA3' and 5'TTTCCCGCCATAGAATATGTGAGA3', and it is in coupling phase with the resistant allele. Typically most of the SSR markers exhibit a co-dominant inheritance (Ferreira and Grattapaglia, 1998). However, the marker amplified by the primer PV-atct 001 , linked to the dominant allele for angular leaf spot resistance, showed dominant inheritance (Table 1). Liu et al. (2001) also iden-

Table 1 - Segregation of the RAPD OPP07 and the SSR PV- atct 001 markers among $\mathrm{F}_{2: 3}$ families from 'ESAL 550' $\mathrm{x}$ 'Carioca MG'.

\begin{tabular}{lcclc}
\hline Locus & $\begin{array}{c}\text { Observed } \\
\text { frequencies }\end{array}$ & $\begin{array}{c}\text { Expected } \\
\text { rate }\end{array}$ & $\chi^{2}$ & $\begin{array}{c}\text { Probability } \\
(\%)\end{array}$ \\
\hline OPP07 $857 \mathrm{C}$ & $96: 24$ & $3: 1$ & 1.6 & 20.5903 \\
PV-atct $001_{282 \mathrm{C}}$ & $94: 26$ & $3: 1$ & 0.711 & 39.9075 \\
\hline
\end{tabular}




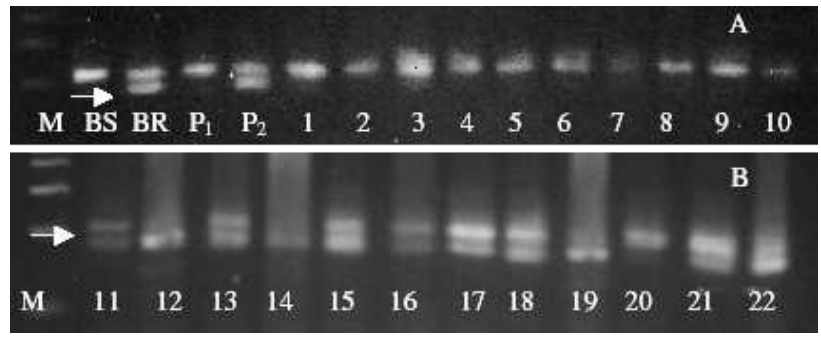

Figure 1 - DNA band pattern amplified by the primer SSR PV-atct 001. BR is the resistance bulk. BS is the susceptible bulk. $\mathrm{P}_{2}$ is the 'ESAL 550'

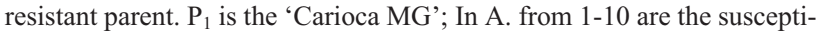
ble $F_{2: 3}$ families; In $B$. from 11-22 are the resistant $F_{2: 3}$ families; $M$ is the $100 \mathrm{pb}$ Promega DNA ladder. The arrow indicates the polymorphic band of $282 \mathrm{bp}$

tified dominant SSR markers and stated that this might happen due to point mutation at primer site in the susceptible parent, or insertion or deletion between the primer sites, preventing amplification or identification in the gel. One or more of these events might have happened with the PV-atct $001_{282 \mathrm{C}}$ marker.

A number of RAPD markers have been identified associated to the common bean alleles resistant to $P$. griseola. For example, Nietsche et al. (2000) found two RAPD markers, OPNO2 $2_{890}$ and OPE04 ${ }_{650}$, linked to resistance to angular leaf spot in the cultivar 'Cornell 49-242', located at 3.2 and $12.5 \mathrm{cM}$ from the locus, respectively. Ferreira et. al (2000) found a marker amplified by the primer OPE04 at $5.8 \mathrm{cM}$ away from the resistance allele in the cultivar 'MAR-2'. The resistance allele of 'BAT 332' was also identified by two RAPD markers (OPAA07950 and OPAO12 950 ), linked in coupling phase to that allele at a distance of 5.10 and $5.83 \mathrm{cM}$, respectively (Caixeta, 2002). The resistant allele of the Andean cultivar 'AND 277' was also identified by the primer OPH13 $3_{490 \mathrm{C}}$ (Carvalho et al. 1998). However, none of them showed amplification in the cross 'ESAL 550' $\mathrm{x}$ 'Carioca MG' utilized in the present study, which suggests that the angular leaf spot resistance allele of the line 'ESAL 550' is different from the reaction genes from other common bean cultivars. There might also have been a repeatability problem in the amplification by those reported RAPD primers.

In the co-segregation analysis among the markers and the resistance allele, it was found that $\mathrm{OPP} 07_{857 \mathrm{C}}$ and the microsatellite PV-act $001_{282 \mathrm{C}}$ were linked to the resistance allele and linked between them (Table 2).

The genetic distances and respective LOD scores, their standard errors and confidence intervals are presented in Table 3. Considering that 5\% error is the cutting point of the LOD score to be 0.83 , as suggested by Lander and Botstein (1989), when only a genetic marker is tested, it was indeed ascertained that the two markers were linked to the resistance allele. However, they are located only on one of its sides as illustrated in Figure 2.
Table $2-\chi^{2}$ test of the segregation observed among the $F_{2: 3}$ families. considering independent assortment of the markers and the reaction gene loci pairwise.

\begin{tabular}{lcccc}
\hline Loci & $\begin{array}{c}\text { Observed fre- } \\
\text { quencies } \\
\text { AB:Ab:aB:ab }\end{array}$ & $\begin{array}{c}\text { Expected fre- } \\
\text { quencies } \\
\text { AB:Ab:aB:ab }\end{array}$ & $\chi^{2}$ & $\begin{array}{c}\text { Prob. } \\
(\%)\end{array}$ \\
\hline OPP07/ R allele & $83: 7: 13: 17$ & $9: 3: 3: 1$ & $30.2^{* *}$ & 0.00 \\
PV-atct 001/ & $88: 2: 6: 24$ & $9: 3: 3: 1$ & $73.3^{* *}$ & 0.00 \\
R allele & $86: 8: 10: 16$ & $9: 3: 3: 1$ & $30.9 * *$ & 0.00 \\
$\begin{array}{l}\text { OPP07/ } \\
\text { PV-atct 001 }\end{array}$ & & & & \\
\hline
\end{tabular}

${ }^{\mathrm{a}} \mathrm{AB}$ presence of the both dominant alleles; Ab presence of dominant and susceptible allele; $\mathrm{aB}$ presence of susceptible and dominant allele; ab presence of the both susceptible alleles.

Table 3 - Recombination frequencies (r) between the reaction gene and the markers. considering the pairwise co-segregation. and the respective Haldane distance (cM). LOD score. standard error (SE). and inferior $\left(\mathrm{CI}_{\mathrm{I}}\right)$ and superior $\left(\mathrm{CI}_{\mathrm{S}}\right)$ confidence intervals.

\begin{tabular}{lcccccc}
\hline Loci & $\begin{array}{c}\text { Distance } \\
(\mathrm{cM})\end{array}$ & $\begin{array}{c}\mathrm{r} \\
(\%)\end{array}$ & $\begin{array}{c}\text { LOD } \\
\text { score }\end{array}$ & $\mathrm{SE}$ & $\mathrm{CI}_{\mathrm{I}}$ & $\mathrm{CI}_{\mathrm{S}}$ \\
\hline $\begin{array}{l}\text { OPP07/ } \\
\text { R allele }\end{array}$ & 24.4 & 19.20 & 6.33 & 0.04 & 0.11 & 0.27 \\
$\begin{array}{l}\text { PV-atct 001/ } \\
\text { R allele }\end{array}$ & 7.6 & 7.08 & 16.21 & 0.0005 & 0.03 & 0.11 \\
$\begin{array}{l}\text { OPP07/ } \\
\text { PV-atct 001 }\end{array}$ & 21.9 & 17.71 & 6.82 & 0.03 & 0.10 & 0.25 \\
\hline
\end{tabular}

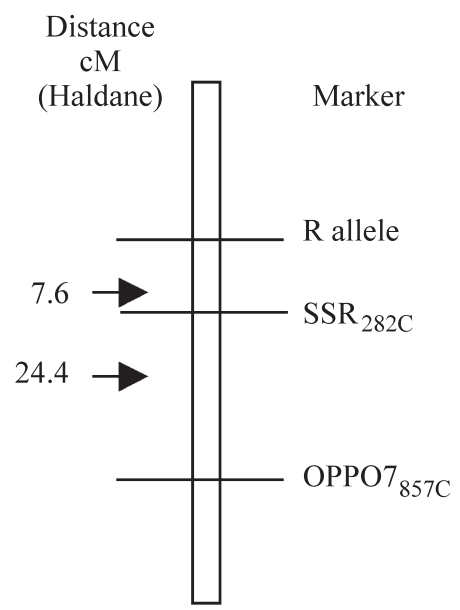

Figure 2 - Partial genetic map showing the gene of reaction to angular leaf spot and the two markers identified in the $\mathrm{F}_{2: 3}$ population of 'ESAL 550' $\mathrm{x}$ 'Carioca MG' cross.

The SSR marker is the most useful of the two for selection because it is closer to the resistance allele (Table 3). The relatively low recombination frequency between the SSR and the locus can be characterized as a useful marker for indirect selection. For example, the expected frequency of susceptible plants selected as resistant in a $\mathrm{F}_{2}$ population is $4.5 \%$ (Table 4 ). In addition, the SSR marker, when ob- 
Table 4 - Expected frequency estimates of susceptible plants (EFESP) selected as resistant in the $\mathrm{F}_{2}$ through the RAPD (OPP07) and SSR (PV-atct 001) markers.

\begin{tabular}{llcc}
\hline \multicolumn{1}{c}{ Primer } & \multicolumn{1}{c}{ Sequence } & $\mathrm{r}(\%)$ & EFESP (\%) \\
\hline OPP07 & 5'GTCCATGCCA3' & 19.20 & 11.56 \\
PV-atct 001 & 5'CAATTAAAACTCAACCAACCCAAATA3' & 7.02 & 4.5 \\
& 5'TTTCCCGCCATAGAATATGTGAGA3' & & \\
\hline
\end{tabular}

tained by a PCR reaction with a larger and specific primer, is more reproducible than the RAPD marker.

The RAPD marker amplified by the primer OPP $07_{857 \mathrm{C}}$, which recombines with the resistant allele at a frequency of $19.2 \%$ would result in the selection of $11.56 \%$ of susceptible plants carrying the marker, as if they were resistant in a $\mathrm{F}_{2}$ generation (Table 4), almost three times less efficient than the SSR marker. Considering the worse repeatability and the larger distance between the marker and the resistance locus, it would be better to use the SSR to help selection.

Finally, it is important to stress the great help that the SSR marker should offer for indirect selection, because in most breeding programs for resistance to angular leaf spot, direct selection under natural incidence of the disease is efficient only in the dry season, once a year. That procedure has been generally adopted because there is great difficulty in causing the disease artificially. With the use of that marker, it would be possible to practice indirect selection at any time of the year.

\section{Conclusion}

The allele of the 'ESAL 550' line resistant to Phaeoisariopsis griseola was tagged by one RAPD marker amplified by the primer OPP07 and one SSR marker amplified by the primer PV-act 001. The SSR is the most useful marker to be used in breeding programs, because it is closer to the resistance allele. The relatively low recombination frequency among them $(7.02 \%)$ characterizes it as a useful marker for indirect selection, due to the small percentage of plants with a marker, erroneously selected in a segregating population.

\section{Acknowlegment}

This project was supported by grant from FAPEMIG, CNPq and CAPES (master's degree scholarship to G.F. da S.)

\section{References}

Allard RW (1956) Formulas and tables to facilitate the calculation of recombination values in heredity. Hilgardia 24:235-278.

Bruzi AT, Silva FB, Ramalho MAP and Abreu, A de FB (2002) Melhoramento visando a resistência à mancha-angular utilizando cultivares de raças andinas e mesoamericanas de feijão. Congresso Nacional de Pesquisa de Feijão, 7, 2002, Viçosa. Resumos. Viçosa: UFV/DFT, pp 207-208.
Caixeta ET (2002) Caracterização da resistência genética à mancha-angular e desenvolvimento de marcadores microssatélite para regiões específicas do genoma do feijoeiro. Tese de Doutorado em Genética e Melhoramento, Universidade Federal de Viçosa, Viçosa, 74 pp.

Carvalho GA, Paula-Júnior TJ, Alzate-Marin AL, Nietsche S, Barros EG and Moreira, MA (1998) Herança da resistência da linhagem AND-277 de feijoeiro-comum à raça 63-23 de Phaeoisariopsis griseola e identificação de marcador RAPD ligado ao gene de resistência. Fitopatologia Brasileira 23:482-485.

Cruz CD and Schuster I (2001) GQMOL: Programa para análise de genética quantitativa molecular. Desenvolvido pelo setor de Genética da Universidade Federal de Viçosa.

Ferreira CF, Borém A, Carvalho GA, Nietsche S, Paula-Júnior, TJ, Barros EG and Moreira, MA (2000) Inheritance of angular leaf spot resistance in common bean and identification of a RAPD marker linked to a resistance gene. Crop Science 40:1130-1133.

Ferreira ME and Grattapaglia D (1998) Introdução ao uso de marcadores moleculares em análise genética. 3 ed. Brasília: EMBRAPA CERNAGEN, 220 pp.

Hagiwara WE, Santos JB dos and Carmo SLM do (2001) Use of RAPD to aid selection in common bean backcross breeding programs. Crop Breeding and Applied Biotechnology 1:355-362.

Lander and ES and Botstein D (1989) Mapping mendelian factors underlying quantitative traits using RFLP linkage maps. Genetics 121:185-199.

Liu XM, Smith CM, Gill BS and Tolmay V (2001) Microsatellite markers linked to six Russian wheat aphid resistance genes in wheat. Theoretical and Applied Genetics 102:504-510.

Mackay IJ and Caligari PDS (2000) Efficiencies de $F_{2}$ and backcross generation for bulked segregant analysis using dominant markers. Crop Science 40:626-631.

Michelmore RW, Paran I and Kesseli V (1991) Identification of markers liked to disease-resistance genes by bulked segregant analysis: a rapid method to detect markers in specific genomic regions by using segregating populations. Proceedings of the National Academy of Sciences USA 88:928-932.

Nietsche S, Borém A, Carvalho GA, Rocha R C, Paula-Júnior TJ, Barros EG and Moreira MA (2000) RAPD and SCAR markers linked to a gene conferring resistance to angular leaf spot in common bean. Journal of Phytopathology 148:117-121.

Paula-Júnior TJ and Zambolim L (1998). Doenças. In: Vieria C, Paula-Júnior, TJ and Borém A (eds) Feijão: aspectos gerais e cultura no Estado de Minas. Viçosa: Editora UFV, pp 375433.

Rogers SO and Bendich AJ (1988) Extraction of DNA from plant tissues. Plant Molecular Biology Manual A6, [s. 1], 6: 1-10. 
Santos ML and Braga MJ (1998). Aspectos econômicos. In: Vieria C, Paula-Júnior TJ and Borém A (eds) Feijão: aspectos gerais e cultura no Estado de Minas. Viçosa, Editora UFV, pp 10-53.

Sartorato A (2002) Resistência do feijoeiro comum à mancha angular. Congresso Nacional de Pesquisa de Feijão, 7, 2002, Viçosa. Resumos. Viçosa: UFV/DFT, pp 117-118.

Sartorado A and Rava CA (1994) Principais doenças do feijoeiro comum e seu controle. Brasília: EMBRAPA, 300 pp.

Schuster I (2002) Método da Máxima verorossimilhaça: a base para o mapeamento genético. http://www.bioagro.ufv.br/ labs/biomol/seminarios/Veross/veross. htm. Acesso em $12 / 2002$.
Texeira SM and Thung MDT (1994) Sócio-economia e tecnologia de produção: o caso das culturas melhoradas de feijão (Phaseolus vulgaris L). In: Texeira SM and Thung MDT (eds) Brasília: EMBRAPA/SPDS, 186 pp.

Vanderplank JE (1963) Plant diseases: epidemics and control. New York: Academic Press, 349 pp.

Yu K, Park SJ, Poysa V and Gepts P (2000) Integration of simple sequence repeat (SSR) markers into a molecular linkage map of common bean (Phaseolus vulgaris L.). The Journal of Heredity 91:429-434.

Editor: Márcio de Castro da Silva Filho 